\title{
'Candidatus Phytoplasma tamaricis', a novel taxon discovered in witches'-broom-diseased salt cedar (Tamarix chinensis Lour.)
}

\author{
Yan Zhao, ${ }^{1}$ Qingrong Sun, ${ }^{1,2}$ Wei Wei, ${ }^{1}$ Robert E. Davis, ${ }^{1}$ Wei Wu ${ }^{1}$ \\ and Oingzhong Liu ${ }^{1,2}$ \\ ${ }^{1}$ Molecular Plant Pathology Laboratory, USDA-Agricultural Research Service, Beltsville, MD 20705, \\ USA \\ ${ }^{2}$ Shandong Institute of Pomology, Taian 271000, PR China
}

Correspondence

Yan Zhao

yan.zhao@ars.usda.gov
Phytoplasmas are non-helical, mycoplasma-like cell-wallless bacteria that are classified in the class Mollicutes. Characterized by AT-rich, reductively evolved genomes and a transkingdom parasitic lifestyle, phytoplasmas are known to be pathogenic to more than a thousand plant species and are transmitted by insect vectors, mainly leafhoppers and psyllids (McCoy et al., 1989; Marcone et al., 1999; Lee et al., 2000; Seemüller et al., 2002; Hogenhout et al., 2008). In infected plants, phytoplasmas inhabit the sieve cells of phloem tissue and induce disease symptoms involving disrupted hormonal balance, impaired amino acid and carbohydrate translocation, inhibited photosynthesis and rapid senescence (Chang, 1998; Lepka et al., 1999; Bertamini et al., 2002a, b; Curković-Perica et al., 2007). In their natural insect vectors, phytoplasmas traverse the intestinal wall, circulate in the haemolymph and multiply in diverse tissues including salivary glands,

Abbreviation: SCWB, salt cedar witches'-broom disease.

The GenBank/EMBL/DDBJ accession number for the 16s rRNA gene sequence of 'Candidatus Phytoplasma tamaricis' is FJ432664.

The results of PCR amplification from samples of symptomatic salt cedar trees are available as supplementary material with the online version of this paper. where phytoplasma cells become incorporated into saliva and are subsequently injected into plants during feeding in the phloem (Seemüller et al., 2002). Phylogenetic studies of genes encoding 16S rRNAs and multiple housekeeping proteins suggest that extant phytoplasmas share a common evolutionary root and are descended from low $\mathrm{G}+\mathrm{C}$ Gram-positive bacteria in the Bacillus-Clostridium group (Weisburg et al., 1989; Gundersen et al., 1994; Sears \& Kirkpatrick, 1994; Zhao et al., 2005a; Wei et al., 2007, 2008a). Within the monophyletic phytoplasma clade, widely divergent phytoplasma lineages have evolved in adaptation to a broad range of bio- and geo-ecological niches (McCoy et al., 1989; Marcone et al., 1999; Lee et al., 2000; Seemüller et al., 2002; Davis et al., 2005; Wei et al., 2007, 2008b; Cai et al., 2008). Since attempts to isolate and cultivate phytoplasmas in cell-free medium remain unsuccessful, measurable phenotypic characters that are routinely used in microbial classification and taxonomy are essentially inaccessible. To resolve the impediments of phytoplasma taxonomy, the International Research Program for Comparative Mycoplasmology, Phytoplasma/ Spiroplasma Working Team - Phytoplasma Taxonomy Group proposed a genus-level provisional taxon 'Candidatus Phytoplasma', and established guidelines for 
naming 'Ca. Phytoplasma' taxa (IRPCM Phytoplasma/ Spiroplasma Working Team - Phytoplasma Taxonomy Group, 2004). Thus far, 27 ' $C a$. Phytoplasma' taxa have been formally described based on 16S rRNA gene sequence phylogeny and/or biological/phytopathological characteristics (IRPCM Phytoplasma/Spiroplasma Working Team Phytoplasma Taxonomy Group, 2004; Firrao et al., 2005; Lee et al., 2006; Valiunas et al., 2006; Arocha, et al., 2007; Al-Saady et al., 2008). In this article, we describe the molecular characterization of a new phytoplasma asso- ciated with a witches'-broom disease of salt cedar (Tamarix chinensis Lour., family Tamaricaceae) and propose that the salt cedar witches'-broom (SCWB) phytoplasma be considered as a novel ' $\mathrm{Ca}$. Phytoplasma' taxon.

\section{Association of SCWB disease with phytoplasmal infection}

Salt cedar is an ornamental shrub/moderate tree species native to Asia and East Europe and was introduced into

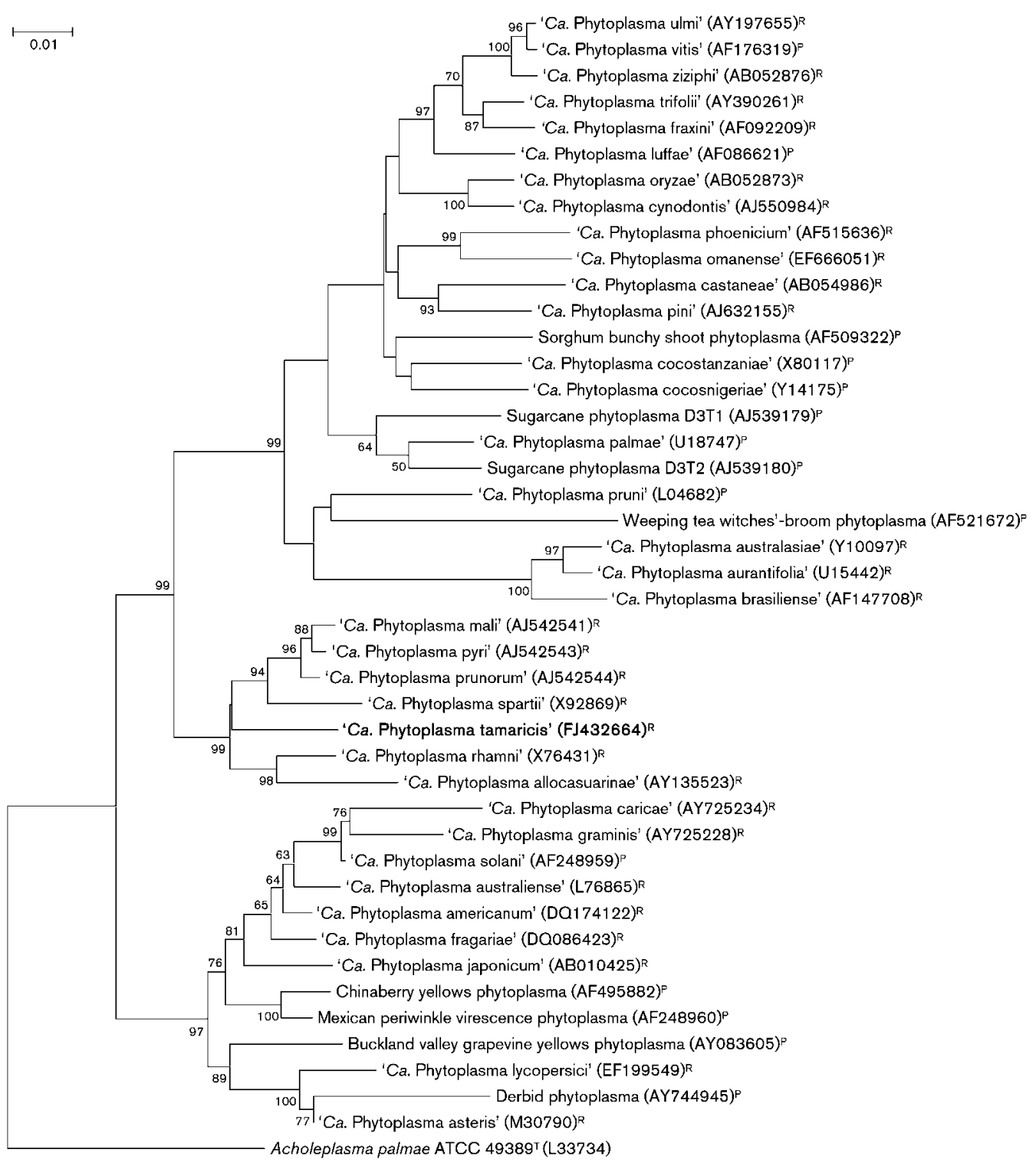

Fig. 1. Phylogenetic tree inferred from analysis of $16 \mathrm{~S}$ rRNA gene sequences. Minimum evolution analysis was conducted using the close neighbour interchange (CNI) algorithm implemented in MEGA4 (Tamura et al., 2007). The initial tree for the CNI search was obtained by the neighbour-joining method. The reliability of the analysis was subjected to a bootstrap test with 1000 replicates. The taxa used in the phylogenetic tree construction included reference strains of 27 previously described 'Ca. Phytoplasma' taxa (labelled with a superscript R), 15 proposed or incidentally cited but yet to be formally described 'Ca. Phytoplasma' taxa (labelled with superscript P) and 'Ca. Phytoplasma tamaricis' (in bold type). Acholeplasma palmae served as an outgroup during the phylogenetic tree construction. Bar, number of nucleotide substitutions per site. 
Table 1. Phytoplasma strains used in the study

\begin{tabular}{|c|c|c|c|}
\hline Strain name & GenBank no. & 16S RFLP group & Reference \\
\hline \multicolumn{4}{|c|}{ Reference strains of formally described ' $C a$. Phytoplasma' taxa } \\
\hline 'Ca. Phytoplasma asteris' & M30790 & 16 SrI-B & Lee et al. (2004a) \\
\hline 'Ca. Phytoplasma aurantifolia' & U15442 & 16 SrII-B & Zreik et al. (1995) \\
\hline 'Ca. Phytoplasma australasiae' & Y10097 & 16SrII-D & White et al. (1998) \\
\hline 'Ca. Phytoplasma ulmi' & AY197655 & $16 \mathrm{SrV}-\mathrm{A}$ & Lee et al. $(2004 \mathrm{~b})$ \\
\hline 'Ca. Phytoplasma ziziphi' JWB-G1 & AB052876 & $16 \mathrm{SrV}-\mathrm{B}$ & Jung et al. (2003a) \\
\hline 'Ca. Phytoplasma trifolii' & AY390261 & 16SrVI-A & Hiruki \& Wang (2004) \\
\hline ‘Ca. Phytoplasma fraxini’ & AF092209 & 16SrVII-A & Griffiths et al. (1999) \\
\hline 'Ca. Phytoplasma phoenicium' & AF515636 & 16SrIX-D & Verdin et al. (2003) \\
\hline 'Ca. Phytoplasma mali’ & AJ542541 & $16 \mathrm{SrX}-\mathrm{A}$ & Seemüller \& Schneider (2004) \\
\hline 'Ca. Phytoplasma pyri' & AJ542543 & 16SrX-C & Seemüller \& Schneider (2004) \\
\hline 'Ca. Phytoplasma spartii' & X92869 & 16SrX-D & Marcone et al. (2004a) \\
\hline 'Ca. Phytoplasma prunorum' & AJ542544 & $16 \mathrm{SrX}-\mathrm{F}$ & Seemüller \& Schneider (2004) \\
\hline 'Ca. Phytoplasma oryzae' & AB052873 & 16SrXI-A & Jung et al. (2003b) \\
\hline 'Ca. Phytoplasma australiense' & L76865 & 16SrXII-B & Davis et al. (1997) \\
\hline 'Ca. Phytoplasma japonicum' & AB010425 & 16SrXII-D & Sawayanagi et al. (1999) \\
\hline 'Ca. Phytoplasma fragariae' & DQ086423 & 16SrXII-E & Valiunas et al. (2006) \\
\hline 'Ca. Phytoplasma cynodontis' & AJ550984 & 16SrXIV-A & Marcone et al. (2004b) \\
\hline 'Ca. Phytoplasma brasiliense' & AF147708 & 16SrXV-A & Montano et al. (2001) \\
\hline 'Ca. Phytoplasma graminis' & AY725228 & 16SrXVI-A & Arocha et al. (2005) \\
\hline 'Ca. Phytoplasma caricae' & AY725234 & 16SrXVII-A & Arocha et al. (2005) \\
\hline 'Ca. Phytoplasma americanum' & DQ174122 & 16SrXVIII-A & Lee et al. (2006) \\
\hline 'Ca. Phytoplasma castaneae' & AB054986 & $16 \operatorname{SrXIX}-\mathrm{A}^{*}$ & Jung et al. (2002); Wei et al. (2007) \\
\hline 'Ca. Phytoplasma rhamni' & $\mathrm{X} 76431$ & 16SrXX-A & Marcone et al. (2004a); Wei et al. (2007) \\
\hline 'Ca. Phytoplasma pini' & AJ632155 & 16SrXXI-A & Schneider et al. (2005); Wei et al. (2007) \\
\hline 'Ca. Phytoplasma allocasuarinae' & AY135523 & Not determined & Marcone et al. $(2004 \mathrm{a})$ \\
\hline 'Ca. Phytoplasma lycopersici' & EF199549 & Not determined & Arocha et al. (2007) \\
\hline 'Ca. Phytoplasma omanense' & EF666051 & 16SrXXIX-A $\dagger$ & Al-Saady et al. (2008) \\
\hline 'Ca. Phytoplasma tamaricis' & FJ432664 & 16SrXXX & Zhao et al. this study \\
\hline \multicolumn{4}{|c|}{ Reference strains of proposed potentially new or incidentally cited taxa } \\
\hline 'Ca. Phytoplasma pruni' & L04682 & 16SrIII-A & $\begin{array}{l}\text { IRPCM Phytoplasma/Spiroplasma Working Team } \\
\text { - Phytoplasma Taxonomy Group (2004) }\end{array}$ \\
\hline 'Ca. Phytoplasma palmae' & U18747 & 16SrIV-A & $\begin{array}{l}\text { IRPCM Phytoplasma/Spiroplasma Working Team } \\
\text { - Phytoplasma Taxonomy Group (2004) }\end{array}$ \\
\hline 'Ca. Phytoplasma cocostanzaniae' & X80117 & Not determined & $\begin{array}{l}\text { IRPCM Phytoplasma/Spiroplasma Working Team } \\
\text { - Phytoplasma Taxonomy Group (2004) }\end{array}$ \\
\hline 'Ca. Phytoplasma vitis' & AF176319 & $16 \mathrm{SrV}-\mathrm{C}$ & $\begin{array}{l}\text { IRPCM Phytoplasma/Spiroplasma Working Team } \\
\text { - Phytoplasma Taxonomy Group (2004) }\end{array}$ \\
\hline 'Ca. Phytoplasma luffae' & AF086621 & 16SrVIII-A & $\begin{array}{l}\text { IRPCM Phytoplasma/Spiroplasma Working Team } \\
\text { - Phytoplasma Taxonomy Group (2004) }\end{array}$ \\
\hline 'Ca. Phytoplasma solani' & AF248959 & 16SrXII-A & $\begin{array}{l}\text { IRPCM Phytoplasma/Spiroplasma Working Team } \\
\text { - Phytoplasma Taxonomy Group (2004) }\end{array}$ \\
\hline 'Ca. Phytoplasma cocosnigeriae' & Y14175 & 16SrXXII-A & $\begin{array}{l}\text { IRPCM Phytoplasma/Spiroplasma Working Team } \\
\text { - Phytoplasma Taxonomy Group (2004); Wei } \\
\text { et al. (2007) }\end{array}$ \\
\hline Mexican periwinkle virescence phytoplasma & AF248960 & 16SrXIII-A & $\begin{array}{l}\text { IRPCM Phytoplasma/Spiroplasma Working Team } \\
\text { - Phytoplasma Taxonomy Group (2004) }\end{array}$ \\
\hline Chinaberry yellows phytoplasma & AF495882 & Not determined & $\begin{array}{l}\text { IRPCM Phytoplasma/Spiroplasma Working Team } \\
\text { - Phytoplasma Taxonomy Group (2004) }\end{array}$ \\
\hline Buckland valley grapevine yellows phytoplasma & AY083605 & 16SrXXIII-A & Wei et al. (2007) \\
\hline Sorghum bunchy shoot phytoplasma & AF509322 & 16SrXXIV-A & Wei et al. (2007) \\
\hline Weeping tea witches'-broom phytoplasma & AF521672 & 16SrXXV-A & Wei et al. (2007) \\
\hline Sugar cane phytoplasma D3T1 & AJ539179 & 16SrXXVI-A & Wei et al. (2007) \\
\hline Sugar cane phytoplasma D3T2 & AJ539180 & 16SrXXVII-A & Wei et al. (2007) \\
\hline Derbid phytoplasma & AY744945 & 16SrXXVIII-A & Wei et al. (2007) \\
\hline
\end{tabular}


Table 1. cont.

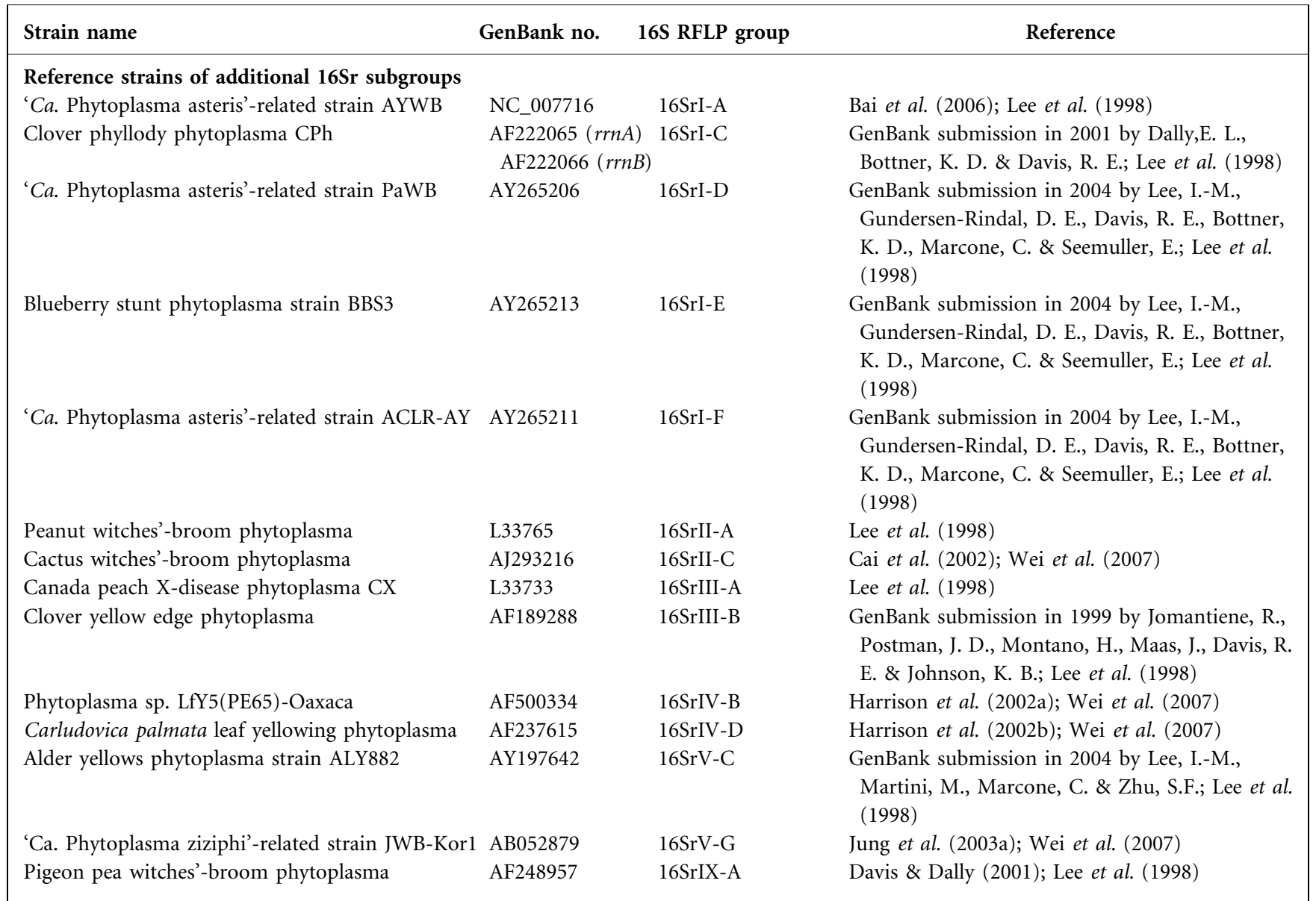

${ }^{\star}$ In the report by Jung et al. (2002), 'Ca. Phytoplasma castaneae' was assigned to group VI according to DNA sequence similarity, rather than results from RFLP analysis. In accordance with the more widely accepted RFLP-based classification system, this phytoplasma was reassigned to group 16SrXIX by Wei et al. (2007).

$\dagger$ The original reference (Al-Saady et al., 2008) reported 'Ca. Phytoplasma omanense' as the reference member of a new group designated group 16SrXIX. However, the group number 16SrXIX had been previously published (Wei et al., 2007) to accommodate a different phytoplasma, 'Ca. Phytoplasma castaneae'. Therefore, we assign 'Ca. Phytoplasma omanense' to a new group, 16SrXXIX, subgroup 16SrXXIX-A.

North America during the 1800s (Baum, 1967). Being an Old World species, salt cedar remains a popular, versatile tree in China as well as in other Asian countries, serving ornamental, medicinal and wind-erosion control purposes (Cheng \& Zhou, 2001). In contrast, in North America, especially in the western United States, salt cedar has recently been considered as an invasive species that has a negative impact on the ecosystem due to its excessive water consumption and natural predators are being sought to control its spread (Knight, 2001; Gaskin, 2003). In the summer of 2004, salt cedar trees with pronounced witches'broom symptoms were observed in a suburb of Xi'an City, China (Zhao et al., 2005b). The diseased trees developed dense clusters of thin and highly proliferating twigs. The internodes of the affected twigs were significantly shortened and the scale-like leaves on the affected twigs were greatly reduced in size. These structural abnormalities gave the affected twigs a ball-like appearance.
Phytoplasma infection was suspected as the cause of this SCWB disease because the disease occurred in an area where phytoplasmal diseases, such as paulownia witches'broom, jujube witches'-broom and wheat blue dwarf have been reported (Kuai et al., 2000). Separate samples of stem/ leaf tissues were collected from six branches of two symptomatic salt cedar trees. Total DNA was extracted from each sample using a combined CTAB-DNeasy (Qiagen) method as described by Green et al. (1999). The DNA preparations served as templates in six independent PCRs in which phytoplasma-universal primer pair, P1/P7 (Deng \& Hiruki, 1991), was used to initiate the amplification reactions. All six reactions yielded an amplicon of approximately $1.8 \mathrm{~kb}$ without the need for a nested PCR (see Supplementary Fig. S1 available in IJSEM Online). Four amplicons (two from each diseased plant) were cloned and sequenced on both DNA strands to achieve a $4 \times$ coverage per base position. Nucleotide 
sequence data revealed that all cloned amplicons were identical and covered a partial rRNA operon, spanning a near full-length $16 \mathrm{~S}$ rRNA gene, a 16S-23S rRNA intergenic spacer, a tRNA-Ile gene and a partial $23 \mathrm{~S}$ rRNA gene. The nucleotide sequence was deposited in GenBank (accession no. FJ432664). The 16S rRNA gene portion of the rRNA operon contained a signature sequence, $\quad{ }_{259} 5^{\prime}$-CAAGACTATGATGTGTAGCTGGACT$3^{\prime}{ }_{283}$, that corresponds to a sequence 5'-CAAGAYBATKATGTKTAGCYGGDCT-3' (IRPCM Phytoplasma/ Spiroplasma Working Team - Phytoplasma Taxonomy Group, 2004) that is characteristic of phytoplasmas. A BLAST (Altschul et al., 1990) search against the nonredundant nucleotide sequence database in the GenBank (http://blast.ncbi.nlm.nih.gov/) using the $1514 \mathrm{bp} 16 \mathrm{~S}$ rRNA gene sequence from the SCWB disease-associated agent as a query returned the most significant matches (with maximum local alignment similarity scores around $96 \%$ ) to the $16 \mathrm{~S}$ rRNA genes of several ' $\mathrm{Ca}$. Phytoplasma prunorum'-, 'Ca. Phytoplasma mali'- and 'Ca. Phytoplasma pyri'-related strains.

The phytoplasma nature of the SCWB disease-associated agent was further confirmed by a phylogenetic analysis of its $16 \mathrm{~S}$ rRNA gene sequence. A phylogenetic tree was constructed using the minimum evolution approach implemented in the MEGA4 program (Tamura et al., 2007). The topology of the phylogenetic tree (Fig. 1) clearly demonstrated that the SCWB disease-associated agent belonged to the phytoplasma clade and shared a common ancestor with ' $\mathrm{Ca}$. Phytoplasma prunorum', ' $\mathrm{Ca}$. Phytoplasma mali', 'Ca. Phytoplasma pyri', 'Ca.

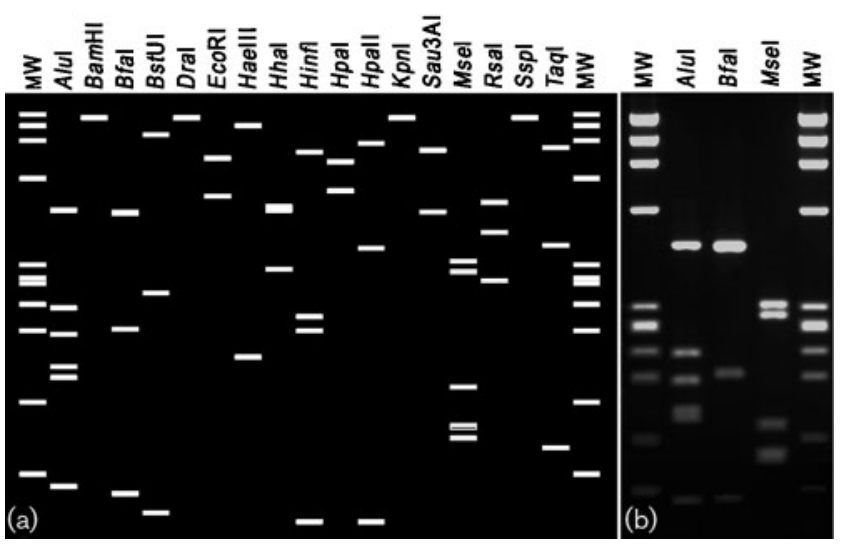

Fig. 2. RFLP profiles derived from $16 \mathrm{~S}$ rRNA gene $\mathrm{F} 2 \mathrm{nR} 2$ fragments of ' $\mathrm{Ca}$. Phytoplasma tamaricis' representative strain SCWB1 (16SrXXX-A). (a) Virtual RFLP patterns derived from in silico digestions using 17 restriction enzymes: $A / u l, B a m H I, B f a l$, BstUl (Thal), Dral, EcoRl, Haelll, Hhal, Hinfl, Hpal, Hpall, Kpnl, Sau3Al (Mbol), Msel, Rsal, Sspl and Taql. (b) Actual restriction patterns derived from digestions using three distinguishing enzymes: Alul, Bfal and Msel. The restriction fragments were resolved by $3 \%$ agarose gel electrophoresis. MW, $\varphi$ X174DNAHaell digestion.
Phytoplasma spartii', 'Ca. Phytoplasma rhamni' and ' $\mathrm{Ca}$. Phytoplasma allocasuarinae', which, except for ' $\mathrm{Ca}$. Phytoplasma rhamni', are members of the apple proliferation phytoplasma group (16SrX). ' $\mathrm{Ca}$. Phytoplasma rhamni' is most closely phylogenetically related to ' $\mathrm{Ca}$. Phytoplasma pyri' and other fruit tree-infecting phytoplasmas (Marcone et al., 2004a) and was previously classified in the group 16SrX (Lee et al., 1998). Recently, this taxon was assigned to a new 16Sr group (16SrXX) on the basis of its lower-than-threshold RFLP pattern similarity coefficient values with all known phytoplasmas in group $16 \mathrm{SrX}$ and other groups (Wei et al., 2007) in accordance with the principle that governs the 16S rRNA gene sequence RFLP-based classification scheme (Lee et al., 1998). Based on the symptoms it produces in its plant host, the signature sequence of its 16S rRNA gene and its phylogenetic position, the SCWB disease-associated agent is hereby designated SCWB phytoplasma, strain SCWB1.

\section{SCWB1 represents a novel taxon}

For overall sequence comparison and pairwise sequence similarity score calculation, a global sequence alignment was constructed using the CLUSTAL $\mathrm{w}$ option of the LASERGENE MEGALIGN program (DNASTAR). The alignment included 16S rRNA gene sequences from SCWB1, from reference strains of all 27 formally described ' $\mathrm{Ca}$. Phytoplasma' taxa and from reference strains of 15 proposed, new but yet to be formally described ' $C a$. Phytoplasma' taxa (Table 1). Exhaustive comparisons of the aligned sequences identified regions unique to the SCWB1 16S rRNA gene. These distinguishing regions include ${ }_{167} 5^{\prime}$-ATTAGGCATCTAGTAACTTTG-3' ${ }_{187}$, $5975^{\prime}$ TGCTCAACATTGTTGC- ${ }^{\prime}{ }_{612},{ }_{971} 5^{\prime}$-AGCTTTGCAAAGTTG- ${ }^{\prime}{ }_{985}$, and ${ }_{994} 5^{\prime}$-TAACAGAGGTTATCAGAGTT- ${ }^{\prime}{ }_{1013}$, which differ in from five to eleven, from three to six, from four to eight and from four to nine base positions, respectively, from the corresponding regions in the $16 \mathrm{~S}$ rRNA genes of all previously described or proposed ' $\mathrm{Ca}$. Phytoplasma' taxa (the original alignment file is available from the authors upon request). Pairwise sequence similarity scores revealed that the 1514 bp near-full-length SCWB1 16S rRNA gene shared no greater than $96.6 \%$ nucleotide sequence similarity with any of the 27 formally described and 15 proposed but yet to be formally described ' $\mathrm{Ca}$. Phytoplasma' taxa (incidental citations). According to recommendations by the IRPCM, Phytoplasma/ Spiroplasma Working Team - Phytoplasma Taxonomy Group (IRPCM Phytoplasma/Spiroplasma Working Team Phytoplasma Taxonomy Group, 2004), 'a strain can be described as a novel ' $\mathrm{Ca}$. Phytoplasma' [candidate] species if its $16 \mathrm{~S}$ rRNA gene sequence has $<97.5 \%$ similarity to that of any previously described ' $\mathrm{Ca}$. Phytoplasma' [candidate] species'. Results from our analysis of the SCWB1 16S rRNA gene, together with the natural host and geographical information, justify the recognition of the SCWB phytoplasma as a novel taxon. Thus, we propose that the phytoplasma strain 


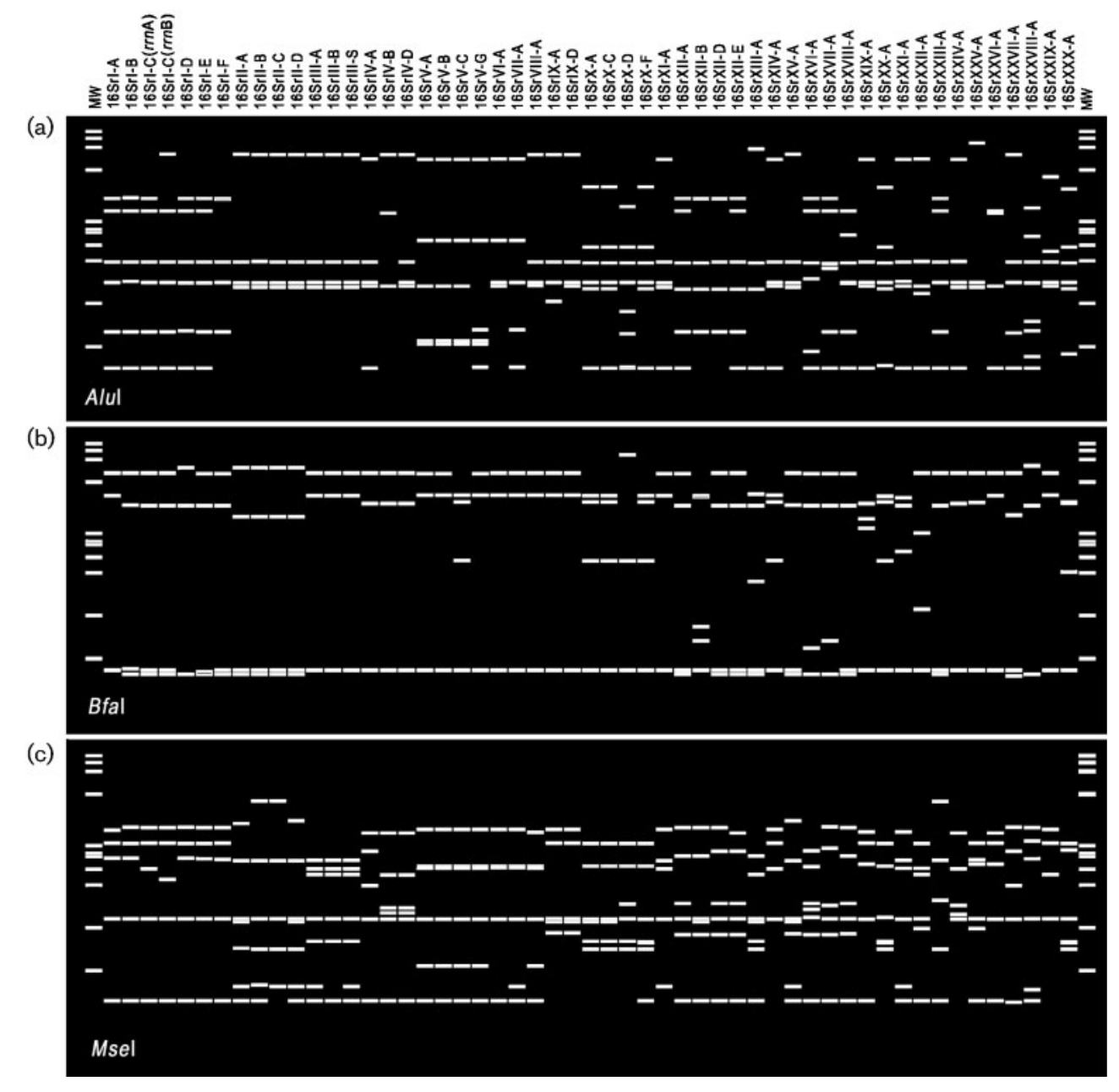

Fig. 3. Distinguishing restriction enzymes that produce unique restriction patterns of the SCWB1 rRNA gene. Subgroup pattern 16SrXXX-A can be distinguished from all other pattern types by Alul (a), Bfal (b) or Msel (c) single enzyme digestion. M, $\varphi X 174 D N A-H a e l l l$ digestion.

SCWB1 be designated the reference strain of a distinct ' $C a$. Phytoplasma' taxon, 'Candidatus Phytoplasma tamaricis'.

\section{SCWB1 represents a new and distinct 165 r RFLP group}

In parallel to 'Candidatus' taxon assignment, phytoplasmas are often classified into groups on the basis of RFLP patterns derived from digestion of the 16S rRNA gene F2nR2 fragment by a set of 17 restriction enzymes, a classification scheme established by Lee et al. (1993). Through periodic updates (Lee et al., 1998, 2000, 2006) and recent expansions through computer-simulated RFLP analysis (Wei et al., 2007, 2008b; Cai et al., 2008), this 16S rRNA gene RFLP-based classification scheme has accommodated 29 groups (16SrI to 16 SrXXIX). Such RFLP pattern-based group classification has provided 'visible' molecular markers for rapid and reliable identification of a broad array of phytoplasmas. In this classification system, the key criterion for the delineation of new $16 \mathrm{Sr}$ groups has been the threshold RFLP pattern similarity coefficient value, which was initially set at 0.9 (Lee et al., 1998) and was recently modified to 0.85 (Wei et al., 2007) to reflect precisely the existing group-level classification status and to guide future recognition of new groups. A new group is recognized if the RFLP pattern derived from a given phytoplasma strain exhibits a similarity coefficient value of lower than 0.85 with the RFLP patterns of all other previously recognized groups.

Virtual RFLP analysis of the ' $\mathrm{Ca}$. Phytoplasma tamaricis' SCWB1 16S rRNA gene F2nR2 fragment revealed a new RFLP pattern (Fig. 2a). The new pattern was confirmed by an actual enzymic RFLP analysis using three distinguishing enzymes AluI, BfaI and MseI (Fig. 2b and Fig. 3). This new pattern had similarity coefficient values lower than 0.77 with the RFLP pattern types of any previously established 
groups (the complete similarity coefficient table is available from the authors on request). The distinct $16 \mathrm{~S}$ rRNA gene RFLP pattern and the lower-than-threshold similarity coefficient values exhibited by the SCWB1 phytoplasma clearly support the recognition of a new 16Sr group, which is hereby designated salt cedar witches'-broom phytoplasma group, $16 \mathrm{SrXXX}$. Erection of this new group is also consistent with the proposal (original group concept) that each 16Sr group represents at least one species (Lee et al., 1998).

Since, at the present time, SCWB1 is the only strain in group 16SrXXX, it becomes the representative strain of subgroup 16SrXXX-A. The unique 16SrXXX-A pattern can be readily distinguished from all other previously delineated $16 \mathrm{Sr}$ group/subgroup patterns by AluI, BfaI or MseI single restriction enzyme digestion (Fig. 3).

\section{Description of 'Candidatus Phytoplasma tamaricis'}

'Candidatus Phytoplasma tamaricis' (tam.ar.i.cis. N.L. gen. n. tamaricis of tamarix, the scientific name of salt cedar; the epithet referring to the plant host).

Reference strain is $\mathrm{SCWB} 1^{\mathrm{R}}$.

[(Mollicutes) NC; NA; O, wall-less; NAS (GenBank accession number FJ432664), oligonucleotide sequences of unique regions of the 16S rRNA gene 5'-ATTAGGCATCTAGTAACTTTG-3', 5'-TGCTCAACATTGTTGC3', 5'-AGCTTTGCAAAGTTG-3' and 5'-TAACAGAGGTTATCAGAGTT-3'; P (Tamarix chinensis, phloem); M]. Zhao et al., this study.

\section{References}

Al-Saady, N. A., Khan, A. J., Calari, A., Al-Subhi, A. M. \& Bertaccini, A. (2008). 'Candidatus Phytoplasma omanense', associated with witches'-broom of Cassia italica (Mill.) Spreng. in Oman. Int J Syst Evol Microbiol 58, 461-466.

Altschul, S. F., Gish, W., Miller, W., Myers, E. W. \& Lipman, D. J. (1990). Basic local alignment search tool. J Mol Biol 215, 403-410.

Arocha, Y., López, M., Piñol, B., Fernández, M., Picornell, B., Almeida, R., Palenzuela, I., Wilson, M. R. \& Jones, P. (2005). 'Candidatus Phytoplasma graminis' and 'Candidatus Phytoplasma caricae', two novel phytoplasmas associated with diseases of sugarcane, weeds and papaya in Cuba. Int J Syst Evol Microbiol 55, 2451-2463.

Arocha, Y., Antesana, O., Montellano, E., Franco, P., Plata, G. \& Jones, P. (2007). 'Candidatus Phytoplasma lycopersici', a phytoplasma associated with 'hoja de perejil' disease in Bolivia. Int J Syst Evol Microbiol 57, 1704-1710.

Bai, X. D., Zhang, J. H., Ewing, A., Miller, S. A., Radek, A. J., Shevchenko, D. V., Tsukerman, K., Walunas, T., Lapidus, A. \& other authors (2006). Living with genome instability: the adaptation of phytoplasmas to diverse environments of their insect and plant hosts. J Bacteriol 188, 3682-3696.

Baum, B. R. (1967). Introduced and naturalized tamarisks in the United States and Canada. Baileya 15, 19-25.
Bertamini, M., Grando, M. S., Muthuchelian, K. \& Nedunchezhian, N. (2002a). Effect of phytoplasmal infection on photosystem II efficiency and thylakoid membrane protein changes in field grown apple (Malus pumila) leaves. Physiol Mol Plant Pathol 61, 349-356.

Bertamini, M., Nedunchezhian, N., Tomasi, F. \& Grando, M. S. (2002b). Phytoplasma [Stolbur-subgroup (Bois Noir-BN)] infection inhibits photosynthetic pigments, ribulose-1,5-bisphosphate carboxylase and photosynthetic activities in field grown grapevine (Vitis vinifera L. cv. Chardonnay) leaves. Physiol Mol Plant Pathol 61, 357366.

Cai, H., Chen, H. R., Li, F. \& Kong, B. H. (2002). First report of a phytoplasma associated with cactus witches'-broom in Yunnan (China). Plant Pathol 51, 394.

Cai, H., Wei, W., Davis, R. E., Chen, H. \& Zhao, Y. (2008). Genetic diversity among phytoplasmas infecting Opuntia species: virtual RFLP analysis identifies new subgroups in the peanut witches'-broom phytoplasma group. Int J Syst Evol Microbiol 58, 1448-1457.

Chang, C.-J. (1998). Pathogenicity of aster yellows phytoplasma and Spiroplasma citri on periwinkle. Phytopathology 88, 1347-1350.

Cheng, L. \& Zhou, G. (2001). Tissue culture and rapid propagation of Tamarix chinensis Lour. J Shanghai Teachers Univ (Natural Sciences) 30, 56-60.

Curković-Perica, M., Lepedus, H. \& Seruga-Musić, M. (2007). Effect of indole-3-butyric acid on phytoplasmas in infected Catharanthus roseus shoots grown in vitro. FEMS Microbiol Lett 268, 171-177.

Davis, R. E. \& Dally, E. L. (2001). Revised subgroup classification of group $16 \mathrm{SrV}$ phytoplasmas and placement of flavescence doréeassociated phytoplasmas in two distinct subgroups. Plant Dis 85, 790-797.

Davis, R. E., Dally, E. L., Gundersen, D. E., Lee, I. M. \& Habili, N. (1997). 'Candidatus phytoplasma australiense', a new phytoplasma taxon associated with Australian grapevine yellows. Int J Syst Bacteriol 47, 262-269.

Davis, R. E., Jomantiene, R. \& Zhao, Y. (2005). Lineage-specific decay of folate biosynthesis genes suggests ongoing host adaptation in phytoplasmas. DNA Cell Biol 24, 832-840.

Deng, S. \& Hiruki, C. (1991). Amplification of $16 \mathrm{~S}$ rRNA genes from culturable and nonculturable Mollicutes. J Microbiol Methods 14, 53-61.

Firrao, G., Gibb, K. \& Streten, C. (2005). Short taxonomic guide to the genus 'Candidatus phytoplasma'. J Plant Pathol 87, 249-263.

Gaskin, J. F. (2003). Molecular systematics and the control of invasive plants: a case study of Tamarix (Tamaricaceae). Ann Mo Bot Gard 90, 109-118.

Green, M. J., Thompson, D. A. \& MacKenzie, D. J. (1999). Easy and efficient DNA extraction from woody plants for the detection of phytoplasmas by polymerase chain reaction. Plant Dis 83, 482-485.

Griffiths, H. M., Sinclair, W. A., Smart, C. D. \& Davis, R. E. (1999). The phytoplasma associated with ash yellows and lilac witches'-broom: 'Candidatus phytoplasma fraxini'. Int J Syst Bacteriol 49, 1605-1614.

Gundersen, D. E., Lee, I.-M., Rehner, S. A., Davis, R. E. \& Kingsbury, D. T. (1994). Phylogeny of mycoplasmalike organisms (phytoplasmas): a basis for their classification. J Bacteriol 176, 5244-5254.

Harrison, N. A., Narváez, M., Almeyda, H., Cordova, I., Carpio, M. L. \& Oropeza, C. (2002a). First report of group $16 \mathrm{SrIV}$ phytoplasmas infecting coconut palms with leaf yellowing symptoms on the Pacific coast of Mexico. Plant Pathol 51, 808.

Harrison, N. A., Womack, M. \& Carpio, M. L. (2002b). Detection and characterization of a lethal yellowing (16SrIV) group phytoplasma in Canary Island date palms affected by lethal decline in Texas. Plant Dis 86, 676-681. 
Hiruki, C. \& Wang, K. (2004). Clover proliferation phytoplasma: 'Candidatus Phytoplasma trifolii'. Int J Syst Evol Microbiol 54, 13491353.

Hogenhout, S.A., Oshima, K., Ammar, el-D., Kakizawa, S., Kingdom, H. N. \& Namba, S. (2008). Phytoplasmas: bacteria that manipulate plants and insects. Mol Plant Pathol 9, 403-423.

IRPCM Phytoplasma/Spiroplasma Working Team - Phytoplasma Taxonomy Group (2004). 'Candidatus Phytoplasma', a taxon for the wall-less, non-helical prokaryotes that colonize plant phloem and insects. Int J Syst Evol Microbiol 54, 1243-1255.

Jung, H. Y., Sawayanagi, T., Kakizawa, S., Nishigawa, H., Miyata, S., Oshima, K., Ugaki, M., Lee, J. T., Hibi, T. \& Namba, S. (2002). 'Candidatus Phytoplasma castaneae', a novel phytoplasma taxon associated with chestnut witches' broom disease. Int J Syst Evol Microbiol 52, 1543-1549.

Jung, H. Y., Sawayanagi, T., Kakizawa, S., Nishigawa, H., Wei, W., Oshima, K., Miyata, S., Ugaki, M., Hibi, T. \& Namba, S. (2003a). 'Candidatus phytoplasma ziziphi', a novel phytoplasma taxon associated with jujube witches'-broom disease. Int $J$ Syst Evol Microbiol 53, 1037-1041.

Jung, H. Y., Sawayanagi, T., Wongkaew, P., Kakizawa, S., Nishigawa, H., Wei, W., Oshima, K., Miyata, S., Ugaki, M. \& other authors (2003b). 'Candidatus Phytoplasma oryzae', a novel phytoplasma taxon associated with rice yellow dwarf disease. Int J Syst Evol Microbiol 53, 1925-1929.

Knight, J. (2001). Alien versus predator. Nature 412, 115-116.

Kuai, Y., Zhang, Z. \& Chen, H. (2000). Phytoplasmal diseases in China. J Yunnan Agric Univ 15, 153-160.

Lee, I.-M., Hammond, R. W., Davis, R. E. \& Gundersen, D. E. (1993). Universal amplification and analysis of pathogen 16S rDNA for classification and identification of mycoplasmalike organisms. Phytopathology 83, 834-842.

Lee, I.-M., Gundersen-Rindal, D. E., Davis, R. E. \& Bartoszyk, I.-M. (1998). Revised classification scheme of phytoplasmas based on RFLP analyses of $16 \mathrm{~S}$ rRNA and ribosomal protein gene sequences. Int J Syst Bacteriol 48, 1153-1169.

Lee, I.-M., Davis, R. E. \& Gundersen-Rindal, D. E. (2000). Phytoplasma: phytopathogenic mollicutes. Annu Rev Microbiol 54, 221-255.

Lee, I. M., Gundersen-Rindal, D. E., Davis, R. E., Bottner, K. D., Marcone, C. \& Seemüller, E. (2004a). 'Candidatus Phytoplasma asteris', a novel phytoplasma taxon associated with aster yellows and related diseases. Int J Syst Evol Microbiol 54, 1037-1048.

Lee, I. M., Martini, M., Marcone, C. \& Zhu, S. F. (2004b). Classification of phytoplasma strains in the elm yellows group (16SrV) and proposal of 'Candidatus Phytoplasma ulmi' for the phytoplasma associated with elm yellows. Int J Syst Evol Microbiol 54, 337-347.

Lee, I.-M., Bottner, K. D., Secor, G. \& Rivera-Varas, V. (2006). 'Candidatus phytoplasma americanum', a phytoplasma associated with a potato purple top wilt disease complex. Int J Syst Evol Microbiol 56, 1593-1597.

Lepka, P., Stitt, M., Moll, E. \& Seemüller, E. (1999). Effect of phytoplasmal infection on concentration and translocation of carbohydrates and amino acids in periwinkle and tobacco. Physiol Mol Plant Pathol 55, 59-68.

Marcone, C., Neimark, H., Ragozzino, A., Lauer, U. \& Seemüller, E. (1999). Chromosome sizes of phytoplasmas composing major phylogenetic groups and subgroups. Phytopathology 89, 805-810.

Marcone, C., Gibb, K. S., Streten, C. \& Schneider, B. (2004a). 'Candidatus Phytoplasma spartii', 'Candidatus Phytoplasma rhamni' and 'Candidatus Phytoplasma allocasuarinae', respectively associated with spartium witches'-broom, buckthorn witches'-broom and allocasuarina yellows diseases. Int J Syst Evol Microbiol 54, 1025-1029.
Marcone, C., Schneider, B. \& Seemüller, E. (2004b). 'Candidatus Phytoplasma cynodontis', the phytoplasma associated with Bermuda grass white leaf disease. Int J Syst Evol Microbiol 54, 1077-1082.

McCoy, R. E., Caudwell, A., Chang, C. J., Chen, T.-A., Chiykowski, L. N., Cousin, M. T., Dale, J. L., DeLeeuw, G. T. N., Golino, D. A. \& other authors (1989). Plant diseases associated with mycoplasma-like organisms. In The Mycoplasmas, vol. V, pp. 545-640. Edited by R. F. Whitcomb \& J. G. Tully. New York: Academic Press.

Montano, H. G., Davis, R. E., Dally, E. L., Hogenhout, S., Pimentel, J. P. \& Brioso, P. S. (2001). 'Candidatus Phytoplasma brasiliense', a new phytoplasma taxon associated with hibiscus witches'-broom disease. Int J Syst Evol Microbiol 51, 1109-1118.

Sawayanagi, T., Horikoshi, N., Kanehira, T., Shinohara, M., Bertaccini, A., Cousin, M. T., Hiruki, C. \& Namba, S. (1999). 'Candidatus phytoplasma japonicum', a new phytoplasma taxon associated with Japanese Hydrangea phyllody. Int J Syst Bacteriol 49, 1275-1285.

Schneider, B., Torres, E., Martín, M. P., Schröder, M., Behnke, H. D. \& Seemüller, E. (2005). 'Candidatus Phytoplasma pini', a novel taxon from Pinus silvestris and Pinus halepensis. Int J Syst Evol Microbiol 55, 303-307.

Sears, B. B. \& Kirkpatrick, B. C. (1994). Unveiling the evolutionary relationships of plant-pathogenic mycoplasmalike organisms. ASM News 60, 307-312.

Seemüller, E. \& Schneider, B. (2004). 'Candidatus Phytoplasma mali', 'Candidatus Phytoplasma pyri' and 'Candidatus Phytoplasma prunorum', the causal agents of apple proliferation, pear decline and European stone fruit yellows, respectively. Int J Syst Evol Microbiol 54, 1217-1226.

Seemüller, E., Garnier, M. \& Schneider, B. (2002). Mycoplasmas of plants and insects. In Molecular Biology and Pathogenicity of Mycoplasmas, pp. 91-115. Edited by S. Razin \& R. Herrmann. New York: Kluwer Academic/Plenum.

Tamura, K., Dudley, J., Nei, M. \& Kumar, S. (2007). MEGA4: molecular evolutionary genetics analysis (MEGA) software version 4.0. Mol Biol Evol 24, 1596-1599.

Valiunas, D., Staniulis, J. \& Davis, R. E. (2006). 'Candidatus Phytoplasma fragariae', a novel phytoplasma taxon discovered in yellows diseased strawberry, Fragaria $\times$ ananassa. Int $J$ Syst Evol Microbiol 56, 277-281.

Verdin, E., Salar, P., Danet, J. L., Choueiri, E., Jreijiri, F., El Zammar, S., Gélie, B., Bové, J. M. \& Garnier, M. (2003). 'Candidatus phytoplasma phoenicium' sp. nov., a novel phytoplasma associated with an emerging lethal disease of almond trees in Lebanon and Iran. Int $J$ Syst Evol Microbiol 53, 833-838.

Wei, W., Davis, R. E., Lee, I.-M. \& Zhao, Y. (2007). Computersimulated RFLP analysis of $16 \mathrm{~S}$ rRNA genes: identification of ten new phytoplasma groups. Int J Syst Evol Microbiol 57, 1855-1867.

Wei, W., Davis, R. E., Jomantiene, R. \& Zhao, Y. (2008a). Ancient, recurrent phage attacks and recombination events shaped dynamic sequence-variable mosaic structures at the root of phytoplasma genome evolution. Proc Natl Acad Sci U S A 105, 11827-11832.

Wei, W., Lee, I.-M., Davis, R. E., Suo, X. \& Zhao, Y. (2008b). Automated RFLP pattern comparison and similarity coefficient calculation for rapid delineation of new and distinct phytoplasma 16Sr subgroup lineages. Int J Syst Evol Microbiol 58, 2368-2377.

Weisburg, W. G., Tully, J. G., Rose, D. L., Petzel, J. P., Oyaizu, H., Yang, D., Mandelco, L., Sechrest, J., Lawrence, T. G. \& other authors (1989). A phylogenetic analysis of the mycoplasmas: basis for their classification. J Bacteriol 171, 6455-6467.

White, D. T., Blackall, L. L., Scott, P. T. \& Walsh, K. B. (1998). Phylogenetic positions of phytoplasmas associated with dieback, 
yellow crinkle and mosaic diseases of papaya, and their proposed inclusion in 'Candidatus Phytoplasma australiense' and a new taxon, 'Candidatus Phytoplasma australasia'. Int J Syst Bacteriol 48, 941-951.

Zhao, Y., Davis, R. E. \& Lee, I. M. (2005a). Phylogenetic positions of 'Candidatus Phytoplasma asteris' and Spiroplasma kunkelii as inferred from multiple sets of concatenated core housekeeping proteins. Int J Syst Evol Microbiol 55, 2131-2141.
Zhao, Y., Sun, Q., Davis, R. E. \& Liu, Q. (2005b). New witches'-broom diseases in northern China and their association with diverse phytoplasmas. Phytopathology 95, S117-S118.

Zreik, L., Carle, P., Bové, J. M. \& Garnier, M. (1995). Characterization of the mycoplasmalike organism associated with witches'-broom disease of lime and proposition of a Candidatus taxon for the organism, 'Candidatus Phytoplasma aurantifolia'. Int J Syst Bacteriol 45, 449-453. 